University of Florida Levin College of Law

UF Law Scholarship Repository

2014

\title{
Borrowing By Any Other Name: Why Presidential "Spending Cuts" Would Still Exceed the Debt Ceiling
}

Neil H. Buchanan

University of Florida Levin College of Law, neil.h.buchanan@law.ufl.edu

Michael C. Dorf

Follow this and additional works at: https://scholarship.law.ufl.edu/facultypub

Part of the Public Law and Legal Theory Commons

\section{Recommended Citation}

Neil H. Buchanan \& Michael C. Dorf, Borrowing By Any Other Name: Why Presidential "Spending Cuts" Would Still Exceed the Debt Ceiling, 114 Colum. L. Rev. Sidebar 44 (2014)

This Article is brought to you for free and open access by the Faculty Scholarship at UF Law Scholarship Repository. It has been accepted for inclusion in UF Law Faculty Publications by an authorized administrator of UF Law Scholarship Repository. For more information, please contact kaleita@law.ufl.edu. 


\title{
COLUMBIA LAW REVIEW SIDEBAR
}

\author{
VOL. 114 \\ MARCH 11, 2014

\section{BORROWING BY ANY OTHER NAME: WHY \\ PRESIDENTIAL “SPENDING GUTS" WOULD STILL EXCEED THE DEBT CEILING}

PAGES 26-50

\author{
Neil H. Buchanan* E Michael C. Dorf***
}

On multiple occasions since mid-2011, the United States has come perilously close to exhausting its borrowing authority under a statutory limit commonly called the "debt ceiling." In prior work, we argued that, in the event that the debt ceiling is reached, the President will face a "trilemma" in which any realistic action he takes-defaulting on government obligations, raising taxes, or issuing debt in excess of the statutory ceiling-would unconstitutionally usurp legislative power. We argued that in such circumstances, violating the debt ceiling would be the "least unconstitutional option." Nonetheless, most pundits and politicians, including the President, appear to assume that if the debt ceiling is reached, default would be necessary. Here, we observe a previously unnoticed deficiency in this assumption: Default would not only usurp congressional power to set spending levels; it also would not even satisfy the debt ceiling, because failure to pay money due on government obligations is a kind of borrowing, both for statutory and constitutional purposes. A "loan" taken from the lender involuntarily is hardly better than consensual borrowing. The government could avoid this result only by expressly repudiating its obligations; doing so, however, would violate even the very narrow construction of Section 4 of the Fourteenth Amendment advanced by those who treat default as the necessary consequence of congressional failure to raise the debt ceiling.

\section{INTRODUCTION}

A federal law commonly known as the debt ceiling purports to limit the amount that the government may borrow. What options would the President have if Congress were to fail to amend the debt ceiling statute to authorize sufficient borrowing to cover the gap between mandated

* Professor of Law, The George Washington University Law School, and Senior Fellow at the Taxation Law and Policy Research Institute, Monash University.

** Robert S. Stevens Professor of Law, Cornell University Law School. The authors thank Nicholas Kelly, Justin Mungai Ndichu, and Trisha Pande for excellent research assistance. 
spending and revenue raised through taxation? That issue has come to a head four times since the middle of 2011 and could arise again, perhaps as early as March 2015, when the most recent suspension of the debt ceiling will expire. Although Republican Speaker of the House John Boehner offered observers a pleasant surprise when he brought a "clean" debt ceiling bill to the House floor in February 2014, by merely suspending the debt ceiling for one year, rather than repealing it, Congress reserved to itself the power to create future crises for President Obama and his successors.

In a series of articles in the Columbia Law Review and the Columbia Law Review Sidebar, ${ }^{1}$ we argued that congressional failure to raise the debt ceiling would present the President with a "trilemma." That is, the President would have three main options, all of which would be bad. ${ }^{3}$ First, he could fail to pay some federal obligees in full and on time. ${ }^{4}$ Second, he could collect more tax revenue than the law authorizes. ${ }^{5}$ Third, he could order the Treasury to borrow enough money to avoid default, even though that would require him to increase total borrowing above the statutory limit. ${ }^{6}$

1. Neil H. Buchanan \& Michael C. Dorf, How to Choose the Least Unconstitutional Option: Lessons for the President (and Others) from the Debt Ceiling Standoff, 112 Colum. L. Rev. 1175 (2012) [hereinafter Buchanan \& Dorf, How to Choose]; Neil H. Buchanan \& Michael C. Dorf, Bargaining in the Shadow of the Debt Ceiling: When Negotiating over Spending and Tax Laws, Congress and the President Should Consider the Debt Ceiling a Dead Letter, 113 Colum. L. Rev. Sidebar 32 (2013) [hereinafter Buchanan \& Dorf, Bargaining in the Shadow]; Neil H. Buchanan \& Michael C. Dorf, Nullifying the Debt Ceiling Threat Once and for All: Why the President Should Embrace the Least Unconstitutional Option, 112 Colum. L. Rev. Sidebar 237 (2012) [hereinafter Buchanan \& Dorf, Nullifying the Debt Ceiling].

2. E.g., Buchanan \& Dorf, How to Choose, supra note 1, at 1196-97 (explaining, thanks to "interaction of the spending law, the tax law, and the debt ceiling law," President "faces a 'trilemma': a choice between three bad options, all of which are unconstitutional").

3. Id. at 1197.

4. Id. at 1179 ("Failure to pay bondholders, contractors, employees, and other persons entitled to money under federal law would have violated Section 4 of the Fourteenth Amendment and, in addition, the President's obligation to 'take Care that the Laws' creating the relevant obligations 'be faithfully executed' ...." (quoting U.S. Const. art. II, §3)).

5. Id. (describing "unilateral actions to increase government revenue, such as a presidential decree raising taxes or a presidential sale of government property without congressional authorization" as violating separation of powers).

6. See id. (" $[\mathbf{I}]$ ssuing new debt without congressional authorization would ... violate[] the separation of powers ...."). In both our prior work and here, we call the President's predicament a trilemma for analytical clarity. A President could mix and match unauthorized spending cuts, unauthorized taxation, and unauthorized borrowing in order to bring the ledger into balance. In addition, he could usurp other powers, such as selling government property without congressional authorization. Thus, a full account of the President's options would describe them as presenting a "multilemma." 
These three options are not merely bad, however; they are all unconstitutional. Even so, we argued that the Constitution guides a President's choice among nothing but unconstitutional options. ${ }^{7}$ Facing a trilemma would not give a President a free pass, but would instead force him to choose how to do the least constitutional damage, even when Congress has failed in its duties under the Constitution. ${ }^{8}$ For reasons that we briefly review below, we concluded that the President's least unconstitutional choice would be to issue additional debt, in the minimum amount necessary to cover all federal obligations. ${ }^{9}$

In this Essay, we return to these issues to make two new points. First, we show that the President would still violate the debt ceiling, even if he purported to honor the debt ceiling by breaching the government's legal obligations through unilateral "spending cuts." 10 He would do so because he would almost certainly be forced to promise that the people whose obligations had not been paid would ultimately be made whole. In so doing, the President would not only have usurped Congress's authority under the spending power (by failing to pay the bills that Congress had committed the nation to pay), but he would also have kept alive the very obligations that would push the total level of federal debt above the statutory limit. A promise to pay is, after all, a debt-not simply according to common sense but also in light of the technical language of the relevant statutes. ${ }^{11}$ The unilateral imposition by the President of forced loans from government obligees would thus usurp Congress's borrowing power as well. "Borrowing" money without consent of either Congress or the lender is hardly better, from a statutory or constitutional viewpoint, than borrowing without the consent of Congress but with the lender's consent. And from a moral and policy viewpoint, it is clearly worse.

To be sure, the President could avoid breaching the debt ceiling and avoid unauthorized borrowing by repudiating outright the obligations that came due after the Treasury had exhausted its ability to finance ongoing expenditures. But this brings us to our second key point: If the President were to repudiate government obligations, then he would be engaging in a clear violation of Section 4 of the Fourteenth Amendment, which forbids the United States from doing anything that would cause "the validity of the public debt" to be "questioned." 12

The trilemma argument we have previously developed rests solely on principles of separation of powers. Even so, public discussions of debt ceiling doomsday scenarios have sometimes assumed that the Fourteenth

7. See id. at 1197.

8. Id. at 1198 .

9. See id. at 1243.

10. We put "spending cuts" in quotation marks because, as we explain below, the President cannot actually cut spending. What most commentators describe as spending cuts are better described as presidential default. See infra text accompanying notes 42-43.

11. See infra Part II.A.

12. U.S. Const. amend. XIV, $\S 4$. 
Amendment poses the only constraint on a President's unilateral decision not to spend the money that Congress has ordered him to spend. Some leading proponents of unilateral default argue that the Fourteenth Amendment only forbids outright repudiation of spending obligations, and not mere delays in payment. ${ }^{13}$ We think that such a reading of the Fourteenth Amendment is too narrow, but here we put that disagreement aside to note what even the skeptics acknowledge: Actual repudiation of federal debt would violate the Fourteenth Amendment.

Thus, even if one thinks that unilateral presidential spending cuts are, in our schema, the least unconstitutional option, or even if one rejects our entire framework because she thinks that unilateral presidential spending cuts do not usurp Congress's spending power, ${ }^{14}$ unilateral presidential spending cuts are still problematic because they would still present a dilemma: Anyone who wants to say that the Fourteenth Amendment cannot be used to justify paying the government's bills by borrowing in excess of the debt ceiling can do so only by saying that any unpaid obligations will eventually be paid in full; doing that, however, keeps alive debts that exceed the debt ceiling, which is a usurpation of Congress's borrowing power.

Under our original analysis of the separation of powers, the President would be required to honor the spending and taxing laws by setting aside the debt ceiling law. He thus would be forced to choose one constitutional violation, because that would be a less serious violation than the two alternatives. We continue to believe that this analysis is correct, and, with the exception of conclusory statements to reporters and short opinion pieces ${ }^{15}$ no other scholars have even engaged with our framework for analysis, much less seriously challenged our conclusions under that analysis.

Our argument here, however, reaches the same conclusion via a different route. Even if one doubts (or outright rejects) our "least

13. See, e.g., Michael McConnell, The Debt Ceiling Is Certainly Not "Unconstitutional," Advancing a Free Society (July 4, 2011, 8:36 AM), http://www. advancingafreesociety.org/exclusive/topics/economics/the-debt-ceiling-is-certainly-not-un constitutional/ (on file with the Columbia Law Review) (explaining, in event debt ceiling is reached, "executive branch will have to make the tough decisions about priorities" as to which payments to postpone); see also Michael Stern, "Threatening Default": A Response to Professor Balkin, Point of Order (July 1, 2011, 6:04 PM), http://www.pointoforder.com/ 2011/07/01/threatening-default-a-response-to-professor-balkin/ (on file with the Columbia Law Review) ("Thus, whatever protection the Clause affords, it applies only to 'debt' and not to 'obligations.'”).

14. But see Buchanan \& Dorf, How to Choose, supra note 1, at 1199-201 (explaining why this view is mistaken).

15. See Michael C. Dorf, Trilemma Watch Continued: Still No Real Substantive Engagement With Our Argument (Oct. 4, 2013, 12:43 PM), http://www.dorfonlaw.org/ 2013/10/trilemma-watch-continued-still-no-real.html (on file with the Columbia Law Review) (compiling list of critiques and expressing frustration with their "shallowness" and failure to address the original argument). 
unconstitutional option" analysis, congressional failure to increase the debt ceiling would force the President to violate the debt ceiling anyway, either by formally issuing additional debt to prevent a default or by breaching the government's obligations in a way that exceeds the debt ceiling. His only alternative would be to repudiate those obligations, which would simply violate the Constitution in a different way.

The combined import of our analysis is that a decision by the President to default on the government's obligations would violate the Constitution in two independent ways. He would usurp Congress's spending power, and he would also either usurp Congress's borrowing power or violate the Fourteenth Amendment. By contrast, issuing debt sufficient to prevent default would "only" violate the borrowing power, and-of some consequence-it could prevent a global economic crisis that would be set into motion by the first-ever default in United States history.

The balance of this Essay proceeds in four parts. In Part I, we briefly recount how the unprecedented strategy of Republicans in the House of Representatives brought the country to the point at which the possibility of default needed to be discussed, and we provide an overview of the range of options that have been considered by politicians, scholars, and other commentators, including our own analysis. In Part II, we explain why presidential default would still require exceeding the debt ceiling and usurp congressional authority to borrow money. In Part III, we explore a previously overlooked connection between the Fourteenth Amendment and separation of powers, explaining why presidential default can only avoid a violation of the latter by violating the former. In Part IV, we contest the view that political constraints take our approach off the table and argue instead that, just as politics can constrain law, so too can effective legal arguments shape politics.

\section{The UnPrecedented DebT CeIling StRATEGy AND the Response IT PROVOKED}

Throughout the democratic world, governments routinely pass laws that dictate certain levels of spending, as well as laws that dictate how much tax revenue will be collected. The difference between spending and revenue, if positive, is financed by borrowing money from the public. Because the U.S. Constitution explicitly confers upon Congress the powers to spend, tax, and borrow, ${ }^{16}$ it is necessary for Congress to explicitly authorize the borrowing that its spending and taxing laws implicitly require.

16. U.S. Const. art. I, \$ 8, cl. 1 ("The Congress shall have Power To lay and collect Taxes, Duties, Imposts and Excises ...."); id. cl. 2 ("The Congress shall have Power ... To borrow Money on the credit of the United States ...."). 
A government can function without a debt ceiling. In fact, we are unaware of any other government (within our federal system, or in another country) that currently operates in the shadow of a debt ceiling law. ${ }^{17}$ In 1917, Congress passed the first debt ceiling law in the United States. ${ }^{18}$ This was actually an attempt, during World War I, to smooth the procedures for borrowing by placing all borrowing authorization in a single statute, rather than having to pass piecemeal borrowing authorizations over time. ${ }^{19}$ Congress thus passed a law that allowed the President to borrow what was needed to execute the budgetary laws. In 1939, however, Congress effectively turned that law into a strict limit, in dollars, on total borrowing by the federal government. ${ }^{20}$ Because the debt limit was not expressed as a percentage of potential national income, ${ }^{21}$ periodic increases in the debt ceiling were required, because the rapidly growing economy was (unsurprisingly) accompanied by increases in the dollar amount of debt.

The existence of a debt ceiling, however, need not create political or budgetary gridlock. For example, during the 1980s and 1990s, the socalled Gephardt Rule in the House of Representatives specified that any

17. Australia had a debt ceiling law until very recently. The ceiling had never become binding, and in 2013, after seeing the havoc resulting in the United States from debt ceiling-related politics, the Australian Parliament repealed it. See Gareth Hutchens, Joe Hockey Cuts Deal with Greens to Scrap Debt Ceiling, Sydney Morning Herald (Dec. 4, 2013), http://www.smh.com.au/federal-politics/political-news/joe-hockey-cuts-deal-withgreens-to-scrap-debt-ceiling-20131204-2yqph.html\#ixzz2mUf9i87F (on file with the Columbia Law Review) (citing "imported Tea-Party style debate" as contributing to repeal decision (internal citation omitted)).

18. Sarah Binder, Op-Ed., Proposing the Unprecedented to Avoid Default: The Law, N.Y. Times: Room for Debate (Jan. 13, 2013, 6:31 PM), http://www.nytimes.com/ roomfordebate/2013/01/13/proposing-the-unprecedented-to-avoid-default/debt-ceilingwas-meant-to-aid-borrow-not-limit-it (on file with the Columbia Law Review); see also Second Liberty Bond Act of 1917, Pub. L. No. 65-43, 40 Stat. 288 (current version at 31 U.S.C. $\$ 3105$ (a) (2012)).

19. Binder, supra note 18 .

20. Id.

21. See 31 U.S.C. $\$ 3101$ (b) ("The face amount of obligations issued under this chapter and the face amount of obligations whose principal and interest are guaranteed by the United States Government... may not be more than $\$ 14,294,000,000,000$, outstanding at one time ...."). Our analysis here clearly shows that there is no good reason to have a debt ceiling statute. If one were to try to write a debt ceiling law that was at least somewhat coherent, however, it would need to limit the debt as a percentage of potential gross domestic product (GDP), not actual GDP. This is because a recession would (by definition) cause GDP to decrease below its potential, which-if a debt ceiling were expressed as a percentage of actual GDP — would require debt to be reduced during a recession, through some combination of tax increases and spending cuts. This, in turn, would only make the recession worse, which would then require further tax increases or spending cuts, and so on. See Neil H. Buchanan, Good Deficits: Protecting the Public Interest from Deficit Hysteria, 31 Va. Tax Rev. 75, 95 (2011) ("Given that tax increases and reductions in spending tend to shrink the economy (at least in the short run), a government that wishes to reduce its overall debt must balance that desire against the danger of creating (or worsening) a recession or depression." (footnote omitted)). 
spending or taxing law that required an increase in borrowing would automatically increase the debt ceiling by the necessary amount. ${ }^{22}$ Republicans ended that rule when they regained the majority in the House in $1995 .{ }^{23}$

In 2011 , as the legally relevant measure of the federal debt neared its statutory limit, the new Republican majority in the House decided to pursue an unprecedented strategy. House Republicans would refuse to increase the debt ceiling, even though doing so would be necessary to avoid default-that is, they would not allow the government to borrow enough money to execute the budgetary laws that the full Congress, including the House itself, had approved-unless the President and Senate Democrats agreed to approve deep cuts in future spending.

Among knowledgeable commentators, the most reasonable reaction to that new political strategy was incredulity. ${ }^{24}$ It seemed implausible that the majority party in one house of Congress could so badly misunderstand the difference between refusing to pay the obligations to which Congress had already committed the United States, and reducing spending in the future. Although there had been prior episodes in which the necessity to vote to increase the debt ceiling had briefly been used to embarrass a President, ${ }^{25}$ no one had ever seriously supposed that either of the political branches (or either political party) could be forced to make concessions on policy simply to prevent the government from defaulting on its obligations. ${ }^{26}$ The United States had never failed to meet its obligations, yet the Republican House majority in 2011 suddenly

22. See H.R. Doc. No. 94-661, at 351 (2013) (“[T] he 'Gephardt rule' used to provide a mechanism for a joint resolution establishing the public debt limit to be automatically generated upon the adoption of the concurrent resolution of the budget.").

23. H.R. Res. 149, 104th Cong. (1995). The Gephardt Rule is also known as "Rule XXVIII," which was the name given to it after its most recent reinstatement in 2001. The rule was ultimately repealed by the 112th Congress in 2011. See H.R. Doc. No. 94-661, at 353 n.1 (chronicling Rule's history of reinstatement and repeal).

24. See generally Neil H. Buchanan, The Debt Ceiling Disasters: How the Republicans Created an Unnecessary Constitutional Crisis and How the Democrats Can Fight Back (2013) (reviewing contemporary commentary on Republican congressional tactics).

25. One such occasion occurred in 2006, when then-Senator Obama cast a vote against increasing the debt ceiling - but only after it was clear that the increase would pass, notwithstanding his vote. Devin Dwyer, Gibbs: Senator Obama Only Voted Against Raising Debt Ceiling in 2006 Because He Knew It Would Pass Anyway, ABC News: Political Punch (Jan. 5, 2011, 3:00 PM), http://abcnews.go.com/blogs/politics/2011/01/gibbs-senatorobama-only-voted-against-raising-debt-ceiling-in-2006-because-he-knew-it-would-pass-an/ (on file with the Columbia Law Review).

26. In some prior political tussles over the debt ceiling, such as in 1985 , matters became so heated that it became necessary for the Treasury to engage in "extraordinary measures" to avoid default, while the principals reached an agreement. See Mindy R. Levit et al., Cong. Research Serv., R41633, Reaching the Debt Limit: Background and Potential Effects on Government Operations 4 (2013). However, in no previous incident had the avowed strategy of either party amounted to a commitment to allow the United States to default unless that party's policy demands were met. 
insisted that it would allow the government to default unless the President and the Democratic majority in the Senate capitulated to House Republicans' political demands.

As a consequence of the resulting political standoff, the United States reached the debt ceiling in May 2011, at which point the Treasury Department engaged in "extraordinary measures" to provide additional time for political negotiations to continue. ${ }^{27}$ Ultimately capitulating to many of the Republicans' demands, the President and his party agreed to immediate deep cuts in federal spending, as well as a series of further across-the-board cuts in spending in 2013 and 2014. ${ }^{28}$ In return, Republicans allowed an increase in the debt ceiling by an amount sufficient to avoid default through the end of 2012. ${ }^{29}$

When it again became necessary to increase the debt ceiling, in late 2012, the President announced that he would no longer permit the debt ceiling to be used as a bargaining chip in partisan negotiations. The Republican majority in the House, along with many Republicans in the Senate, initially acted as though they thought the President was bluffing, and thus held out until the eleventh hour. In both February and October 2013, after political standoffs that each came within days of causing federal default, bills were passed to suspend the debt ceiling temporarily. The same result was reached in February 2014, when the Republican Speaker capitulated without putting up a serious fight. ${ }^{30}$

Whether that surrender marks the end of debt ceiling brinksmanship remains to be seen. The 2014 debt ceiling suspension passed with only twenty-eight Republican votes in the House ${ }^{31}$ and no Republican votes in the Senate (although twelve Republican Senators did vote for cloture) ${ }^{32}$ Should the composition of either body change even modestly, the political calculations could change as well, and the debt ceiling could once again be used as a bargaining chip.

27. Id. at 6 .

28. The political standoff over the debt ceiling ended with the passage of the Budget Control Act of 2011. Provisions of the Act included an increase in the debt ceiling, and a series of automatic federal spending cuts set to begin in 2013 and take place through 2021. See Budget Control Act of 2011, Pub. L. No. 112-25, \$\$ 101, 301, 125 Stat. 240, 241$45,251-55$ (codified as amended in scattered sections of 2 U.S.C.).

29. See id. $\$ 301,125$ Stat. at 251-55.

30. See Ashley Parker \& Jonathan Weisman, G.O.P. Senate Leaders Avert Debt Ceiling Crisis, N.Y. Times (Feb. 12, 2014), http://www.nytimes.com/2014/02/13/us/ politics/senate-debt-ceiling-increase.html?_r=0 (on file with the Columbia Law Review) ("Republican leaders ... collectively decided that they needed to quickly dispose of the debt ceiling fight ....").

31. See Jonathan Weisman \& Ashley Parker, House Approves Higher Debt Limit Without Condition, N.Y. Times (Feb. 11, 2014), http://www.nytimes.com/2014/02/12/us /politics/boehner-to-bring-debt-ceiling-to-vote-without-policy-attachments.html (on file with the Columbia Law Review) ("Only 28 Republicans voted yes .... .).

32. Parker \& Weisman, supra note 30. 
Throughout this series of political ordeals, political analysts and legal scholars questioned whether the debt ceiling was constitutional. Was a law that could only be used irresponsibly, to prevent the government from paying its obligations, necessarily be in conflict with the Constitution? Were there other laws or constitutional principles that could be used to circumvent or neutralize the serious threat posed by the debt ceiling (or at least to neutralize the threat posed by the House Republicans' tactic of using the debt ceiling opportunistically to force concessions from their opponents that they could not otherwise extract)?

The prior literature on these questions was understandably sparse. Precisely because the legal consequences that could flow from the misuse of the debt ceiling statute are so serious, and the practical consequences of default almost unthinkably severe, few scholars could have imagined that it would be necessary even to address the situation in which the country first found itself in 2011.

In the ensuing three years, several strands of argument have emerged regarding the debt ceiling. First, there are suggestions that the debt ceiling can be neutralized by financial gimmicks that would allow the government to continue to pay its bills without formally breaching the debt ceiling. Second, a small literature has emerged regarding the question of whether the debt ceiling violates Section 4 of the Fourteenth Amendment. ${ }^{33}$

The first suggested response to the debt ceiling-financial maneuvers designed to evade the debt ceiling by seeming to follow the letter of the law, in an attempt to avoid a constitutional crisis-includes several variations on the same theme, the most well-known of which is the "trillion-dollar coin option," under which the U.S. Treasury would exploit a supposed loophole in the Coinage Act to mint platinum coins with nominal values as large as necessary to cover the government's financial needs. We considered platinum coins and similar options in our first Columbia Law Review article on the debt ceiling, as well as in our popular writings; and we not only concluded that such gimmicks would be unwise, but that they do not even avoid the constitutional difficulties that misuse of the debt ceiling would cause. ${ }^{34}$

33. See, e.g., Jacob D. Charles, Note, The Debt Limit and the Constitution: How the Fourteenth Amendment Forbids Fiscal Obstructionism, 62 Duke L.J. 1227, 1231 (2013) (arguing Congress violates Public Debt Clause "by causing the validity of the public debt to be questioned"); Kelleigh Irwin Fagan, Note, The Best Choice Out of Poor Options: What the Government Should Do (or Not Do) If Congress Fails to Raise the Debt Ceiling, 46 Ind. L. Rev. 205, 207 (2013) (analyzing Public Debt Clause in light of Congress's failure to raise debt ceiling). For an early analysis of this issue, published long before the recent political showdowns over the debt ceiling, see Michael Abramowicz, Beyond Balanced Budgets, Fourteenth Amendment Style, 33 Tulsa L.J. 561 (1997).

34. See, e.g., Buchanan \& Dorf, How to Choose, supra note 1, at 1231 (noting objections to "jumbo coin proposal"); Neil H. Buchanan, Big Coins, Political Credibility, and Hatred of Lawyers, Dorf on Law (Jan. 10, 2013, 10:07 AM), http://www.dorfonlaw.org/ 
The second widely discussed response to the threat of a debt ceiling crisis is that the President should invoke the Fourteenth Amendment's "Public Debt Clause," which prohibits actions that "question[]" the "validity" of the public debt. ${ }^{35}$ We have found significant merit in that argument, although we understand why the imprecise wording of, and sparse postenactment case law interpreting, the relevant clause could leave some room for doubt about how to determine its meaning.

Meanwhile, the Obama White House has explicitly rejected both exotica like platinum coins and the possibility of invoking the Fourteenth Amendment as grounds for issuing debt in excess of the statutory ceiling. ${ }^{36}$ Moreover, the President seems to assume that, because he has decided not to invoke either of those two "Hail Mary" approaches to dealing with Republicans' threats not to increase the debt ceiling, there is only one simple and obvious path that the President must follow. As the White House Press Secretary has repeatedly stated, there are only two options: Either the debt ceiling is increased, or we must default on our obligations for the first time in history. ${ }^{37}$

That statement is simply incorrect. As we have argued in our scholarly articles and popular writing, one cannot simply assume that the debt ceiling trumps all other budgetary laws. If a President were ever to be in the position where the debt ceiling had become truly binding, he would face a trilemma in which each of his realistic options would be unconstitutional.

Our trilemma analysis starts with the essential point that there is no "safe position" that the President can rely upon. That is, he faces nothing but unconstitutional options. Nonetheless, much of the policy conversation has been based on the erroneous belief that the President would be forced to commit a default on some of the government's legally obligated payments if the debt ceiling is not increased as needed. Although that would be one of his options, it is not the only one. More importantly, it is not constitutionally "safe."

When we say that the President would face a trilemma, we mean that he would have to choose among three constitutionally forbidden options: refusing to pay money that Congress appropriated; trying to collect revenues in excess of the amounts that Congress specified; or borrowing more than Congress authorized. All three of those actions by the

2013/01/big-coins-political-credibility-and.html [hereinafter Buchanan, Big Coins] (on file with the Columbia Law Review) (noting problems with trillion-dollar-coin solution).

35. U.S. Const. amend. XIV, $\$ 4$.

36. Catherine Thompson, Obama Dismisses Using Trillion Coin, 14th Amendment Argument to Resolve Debt Ceiling, Talking Points Memo (Oct. 8, 2013, 3:01 PM), http:// talkingpointsmemo.com/livewire/obama-dismisses-14th-amendment-argument-for-liftingdebt-ceiling (on file with the Columbia Law Review).

37. E.g., Jay Carney, White House Press Sec'y, Press Briefing (Oct. 1, 2013), http:// www.whitehouse.gov/the-press-office/2013/10/01/press-briefing-press-secretary-jaycarney-1012013 (on file with the Columbia Law Review). 
President would violate the Constitution, because each of them would see the President usurping Congress's Article I powers to spend, tax, or borrow. ${ }^{38}$

Our point was not and is not that the President violates the Constitution whenever he violates a statute. As one scholar correctly but irrelevantly noted in a blog post, every statutory violation is also, trivially, a constitutional violation, because every statutory violation by the President violates his constitutional duty to take care that the laws are faithfully executed. ${ }^{39}$ Our point is that a President's decision to tax more, borrow more, or spend less than Congress has authorized amounts to a presidential decision to make for himself a policy decision that the Constitution commits to Congress-whereas the President's constitutional role in lawmaking is limited to proposing, signing, or vetoing bills.

The point is easy enough to see with respect to taxing and borrowing. Suppose Congress had never authorized any taxes or borrowing at all. If the President were then to impose some new tax or to borrow money, purportedly on his own authority, the separation of powers violation would be the very one to which we have called attention, even though no statute would be violated.

Based on public discussions of the issue by politicians and a few legal commentators, however, it appears that there continues to be some confusion as to why failing to spend appropriated funds amounts to a nontrivial violation of the Constitution. As we have discussed in all three of our prior articles, the spending power allows Congress (and Congress alone) to decide exactly how much money to spend, and on which projects. ${ }^{40}$ This power fundamentally involves the setting of priorities, with different amounts of spending expressing Congress's collective judgment about the relative importance of, say, sugar price supports, cancer research, military pensions, early childhood nutrition subsidies, and so on.

If the President were to fail to pay for Congress's spending priorities, on time and in full, he would violate the Constitution by usurping Congress's spending power. This was the basis of the Impoundment Crisis during Richard Nixon's Presidency, ${ }^{41}$ which resulted in Congress

38. U.S. Const. art. I, § 8 .

39. Eric Posner, Three Ways Obama Could Raise the Debt Ceiling on His Own: The Controversial, Risky Options if Congress Doesn't Act, New Republic (Oct. 6, 2013), http://www.newrepublic.com/article/115034/debt-ceiling-3-ways-obama-couldcircumvent-congress (on file with the Columbia Law Review).

40. Buchanan \& Dorf, How to Choose, supra note 1, at 1199-200; Buchanan \& Dorf, Bargaining in the Shadow, supra note 1, at 40-42; Buchanan \& Dorf, Nullifying the Debt Ceiling, supra note 1, at 244-47.

41. See Editorial, Don't Blame the Budget Process, N.Y. Times (Oct. 7, 1982), http:// www.nytimes.com/1982/10/07/opinion/don-t-blame-the-budget-process.html (on file with the Columbia Law Review) (describing Impoundment Crisis and implications for budget control). 
passing the Impoundment Control Act, specifically to prevent a President from deciding not to follow Congress's full orders regarding spending. ${ }^{42}$ And as we have repeatedly explained, the Supreme Court's decision in the line-item veto case, Clinton v. New York, makes clear that unless Congress specifically authorizes the President to spend "up to" certain sums, congressional appropriations are to be satisfied in exact amounts, with presidential noncompliance treated as a nontrivial constitutional violation. ${ }^{43}$

Thus, a President would commit a serious constitutional violation (one that is, we would add, potentially an impeachable offense) if he were to default on any U.S. obligation to pay money under the law. Our analysis does not, however, simply assume away the fact that the President's other options-taxing or borrowing without Congress's authorization-are also unconstitutional. The identification of the trilemma is merely the starting point of the analysis. The key question is what to do, when all paths are unconstitutional.

We identified three criteria that should guide a President in choosing the best path forward. First, he should do what can most easily be reversed (if Congress later decides that it does not like his choice).$^{44}$ Second, he should do as little "legislating" as possible, by choosing the option that minimizes the need for the President to make the sorts of judgments and to strike the sorts of balances that Congress engages in when it passes laws. ${ }^{45}$ And third, he should eschew options that, even if arguably legal, would have such extreme real-world consequences as to be worse than violating the Constitution. ${ }^{46}$ We concluded that borrowing the amount necessary to carry out Congress's taxing and spending laws, even if that requires an amount of borrowing that exceeds the debt ceiling, clearly meets those criteria, and is thus the least unconstitutional option. ${ }^{47}$

Although some legal scholars and other commentators have expressed disagreement with some of our conclusions, there does not appear to have been any scholarship arguing the contrary view-that when faced with a trilemma, a President should not violate the debt ceiling because doing so would be more unconstitutional than defaulting on the government's obligations would be. ${ }^{48}$ Because some comment-

42. Congressional Budget and Impoundment Control Act of 1974, Pub. L. No. 93344 , 88 Stat. 297 (codified as amended at 2 U.S.C. $\$ \S 601-688$ ).

43. 524 U.S. 417, 445-47 (1998).

44. Buchanan \& Dorf, How to Choose, supra note 1, at 1214-15.

45. Id. at 1200-01.

46. Id. at 1209-10.

47. Id. at 1243 .

48. Note that we do not discuss here the third option, which is to have the President increase taxes unilaterally. We dealt with that question in our first article, but because the real-world debate has been over only two prongs of the trilemma, we continue to focus only on the borrowing-versus-defaulting question. 
ators (and apparently the White House itself, given its stated belief that it would be forced to default) appear to hold that view, however, we have attempted to respond even to the most cryptic comments that express disagreement with our view. Here, we extend our arguments to deal with possible objections that might be raised against our position.

\section{The Paradox of Debt: Defaulting on Obligations to Avoid Exceeding The Debt CeIling Does Not Avoid ExceEdng the DebT CEILING}

In our scholarship to date, we have assumed that a presidential decision to default would usurp congressional authority to decide how much money to spend, but that it would not violate the Constitution in any other way. In particular, we have assumed that refusing to explicitly borrow in excess of the debt ceiling would at least achieve its obvious immediate goal-allowing the President to avoid exceeding the debt ceiling. He would, under this view, usurp the spending power, but he would not usurp the borrowing power.

As it turns out, however, that concession to our (largely hypothetical) critical interlocutors was not warranted. Indeed, the President cannot prevent the government from exceeding the debt limit, nor from usurping Congress's borrowing power-even if he defaults on required payments under the appropriations laws. These surprising results follow from the statutory definition of debt and the constitutional meaning of borrowing.

\section{A. The Statutory Definition of Debt}

The debt ceiling statute defines "debt" to include more than the government securities that are periodically issued by the Treasury Department. ${ }^{49}$ In a well-crafted attempt to guarantee that form will not dominate substance, Congress wrote the debt ceiling law specifically to include both Treasury securities and a broader, catch-all category of other obligations in its definition of the debt that is covered by the debt ceiling. ${ }^{50}$

49. See 31 U.S.C. $\$ \$ 3101-3106$ (2012) (enumerating types of "obligations" that count towards debt ceiling).

50 . The statutory cap applies to the sum of " $[\mathbf{t}]$ he face amount of obligations issued under this chapter and the face amount of obligations whose principal and interest are guaranteed by the United States Government." 31 U.S.C. \$ 3101(b) (emphasis added). That is, the statute first refers to "obligations" of the federal government issued under chapter 31 of title 31 of the U.S. Code, which authorizes the issuance of the Treasury bonds, notes, and bills through which the federal government generally borrows money. The section then separately refers to all other obligations that are backed by the federal government. See Buchanan, Big Coins, supra note 34 ("The first category applies to the usual Treasury securities... . If Congress wanted the law to limit only the total amount of formal Treasuries, it [would not have] ... added that second category."). As we discuss below, unless the principal amount of any unpaid obligations is repudiated outright, the 
This means that, if a President were to avoid selling securities merely by putting the government into debt in some other way, the President would not successfully evade the debt ceiling. And this is precisely what the President would be doing if he were to default on the government's obligations. He would presumably express regret at the delay in payment, saying that the debt ceiling prevented him from borrowing the funds necessary to make good on the payments that have come due; and he would assure the disappointed obligees that the money would be coming as soon as possible.

But to provide such assurances, of course, is to recognize that the government is in debt to the people who have not yet been paid. The President, rather than borrowing money from people who voluntarily exchange their money now on the promise of receiving principal plus interest later, would force the government's obligees-possibly including Social Security recipients, Medicare providers, military contractors, and so on-to become its unwilling lenders. ${ }^{51}$ The President would, therefore, not have avoided exceeding the debt ceiling at all. Instead, he would have chosen to increase the debt by denying payment to the very people who have the most right to expect payment in full on a specific date.

When does an obligation become a debt? The U.S. Code does not define "obligation" but an answer emerges both from logic and the overall structure of the Code. An obligation becomes a debt exactly on the date that the payment is due. Either the obligation is paid and thus extinguished, or it is unpaid and becomes a debt going forward. This basic logic also means that it is inappropriate to include future obligations (whether measured in nominal dollars, or in net present value) in the measurement of debt. Subject to broad constitutional limits on altering vested rights ${ }^{52}$ future obligations can be altered. For example, Congress could change the formula for paying Social Security benefits without committing a default on legal obligations, even though current recipients may expect that the existing benefit levels will not be changed.

principal and interest (if any is promised) on those unpaid obligations are guaranteed by the federal government. (Note also that, pursuant to the Prompt Payment Act, 31 U.S.C. $\$ \S 3901-3907$ (2012), money due on federal contracts is called "debt," including interest for late payments.) Nothing in the U.S. Code defines "obligations" in a way that would exclude from the debt ceiling's ambit the obligations that Congress creates when it legally commits the government to pay obligees in full, on dates certain. Nor should it, because the statute is clearly an attempt (though ill-considered in all of the other ways that we have identified here and elsewhere) to limit the federal government's total exposure to legal claims for payment - that is, to limit its total obligations.

51. See 31 U.S.C. $\$ \$ 3901-3907$ (characterizing money due to such obligees as "debt").

52. See E. Enters. v. Apfel, 524 U.S. 498, 547-48 (1998) (Kennedy, J., concurring in the judgment and dissenting in part) (describing case law under Due Process Clause limiting retroactive legislation). 
Until those benefits come due, such expectations, no matter how reasonable, are not constitutionally protected.

Importantly, this current-versus-future distinction also explains why it is important to describe the President's constitutional violation as a "default" rather than "cutting spending." Even though the constitutional power at stake is the spending power conferred upon Congress, a presidential decision to violate the spending power by refusing to disburse the funds that Congress has required to be disbursed constitutes a default. Congress "cuts spending" when it passes a budget that reduces the amounts appropriated to be paid during that year, compared to previous years. The President cannot cut spending, but instead can either faithfully execute Congress's spending decisions ${ }^{53}$ or default upon them.

This broader meaning of the word "debt" is also supported by the language Congress used when writing the Prompt Payment Act, which guarantees that federal contractors will be paid in full on the dates specified in legally binding contracts. ${ }^{54}$ Under that law, the President is required either to pay the contractors in full, as specified by law, or to pay interest on the unpaid balance ${ }^{55}$ Notably, Congress specifically used the word "debt" to describe those unpaid balances. ${ }^{56}$ There is nothing exceptional about that usage, reflecting, as it does, the common-sense understanding that money not paid on time becomes a debt. Absent any indication to the contrary in statutory text, there is every reason to treat the government's failure to make other payments on time as becoming debt. ${ }^{57}$

Furthermore, Congress's treatment of the "extraordinary measures" that the Treasury has occasionally used to avoid default speaks to the question of what counts as debt under the law. During an earlier standoff over the debt ceiling, the Treasury temporarily recharacterized debt securities used to finance federal pension obligations as essentially "not debt," allowing it to finance other obligations without defaulting, while

53. U.S. Const. art. II, $\$ 3$ (requiring President to "take Care that the Laws be faithfully executed").

54. 31 U.S.C. $\$ 3902$ (setting interest penalties).

55. Id. In the situation described above, where the President announces a default, he could announce that he will (as soon as Congress agrees) make sure that the disappointed obligees will be paid interest during the period of default. Whether he does so or not, of course, does not mean that default is not a breach of the debt ceiling. It merely raises the question of whether the forced loans will also be interest-free borrowing by the government. Weighing against the bad public relations of refusing to promise to pay interest would be the desire to avoid admitting that these really are forced loans in the first place.

56. See id. \$3902(e) ("An amount of an interest penalty unpaid after any 30-day period shall be added to the principal amount of the debt, and a penalty accrues thereafter on the added amount.").

57. For example, although it does not use the term "debt," the relevant provision of the Social Security Act acknowledges the government's obligation to make additional payments to persons who are underpaid. 42 U.S.C. $\$ 404$ (2006). 
still claiming not to exceed the debt ceiling. ${ }^{58}$ Congress later explicitly approved of that accounting maneuver, designating various pension funds as eligible for such treatment. ${ }^{59}$ Congress thus indicated that it views itself as able to define debt for purposes of the debt ceiling.

\section{B. The Constitutional Definition of Borrowing}

Within very broad limits, Congress can define terms in the laws that it writes, but even when Congress uses language that closely tracks the Constitution, a statutory definition is not necessarily coextensive with the corresponding constitutional language. To give an example that received considerable attention in the recent past, the Supreme Court held that the Patient Protection and Affordable Care Act's minimum coverage provision was a tax for constitutional purposes but was not a tax for purposes of the Anti-Injunction Act. ${ }^{60}$ Although this distinction befuddled many political commentators, there was nothing remotely novel about treating a word or phrase to mean one thing for purposes of statutory construction and something else for purposes of constitutional law. ${ }^{61}$

It is at least possible, therefore, that a violation of the debt ceiling law would not be a violation of the provision of the Constitution's Article I, Section 8 assigning to Congress the power to "borrow Money on the credit of the United States." 62 If such "borrowing" is not the same as accumulating "obligations" under the debt ceiling law, it would be poss-

58. Levit et al., supra note 26, at 4 (detailing Treasury's actions in 1985 to "meet the government's cash requirements" after reaching statutory debt limit).

59. Id. Notwithstanding our statement above that the debt ceiling law is "well-crafted" in its closing of a particular potential loophole, see supra text accompanying note 50 , the law does strangely identify as debt purely internal accounts of the federal government. The "debt held by the public" is much lower than measured debt, mostly because of the internally held securities in the Social Security Trust Funds. Treasury Dep't, TreasuryDirect, The Debt to the Penny and Who Holds It, http://www.treasurydirect.gov/NP/debt/ current (on file with the Columbia Law Review) (last visited Feb. 15, 2014). This raises different questions about Congress's definitions of debt, to which we will turn momentarily.

60. Nat'l Fed'n of Indep. Bus. v. Sebelius, 132 S. Ct. 2566, 2582-83, 2594 (2012).

61. For example, title 28 of the U.S. Code mirrors the language of Article III in its grants of diversity jurisdiction and federal question jurisdiction. Yet the Supreme Court long ago held that both statutory grants are narrower than their constitutional counterparts. Compare Osborn v. Bank of the U.S., 22 U.S. (9 Wheat.) 738, 755-65 (1824) (offering very broad definition of cases "arising under" federal law as term is used in Article III), with Louisville \& Nashville R.R. Co. v. Mottley, 211 U.S. 149, 152-53 (1908) (restricting cases "arising under" federal law as term is used in statutory language found now in title 28 to those in which federal issue appears on face of plaintiff's well-pleaded complaint); compare also Haas v. Jefferson Nat'l Bank of Miami Beach, 442 F.2d 394, 396 (5th Cir. 1971) (" $[\mathrm{T}]$ he diversity statute requires complete diversity of citizenship." (citing Indianapolis v. Chase Nat'l Bank, 314 U.S. 63 (1941))), with State Farm Fire \& Cas. Co. v. Tashire, 386 U.S. 523, 530-31 (1967) (holding Article III requires only minimal diversity).

62. U.S. Const. art. I, § 8, cl. 2. 
ible for a President to take actions that violate the debt ceiling law without violating the Constitution, or vice versa.

In fact, there are limited circumstances in which a presidential action that violated the debt ceiling would not also usurp congressional power to borrow under Article I, Section 8. As noted above, Congress's definition of "debt" in the debt ceiling law is, one might say, idiosyncratic. ${ }^{63}$ Congress includes in its measure of debt the total value of all Treasury securities in existence, including those that are held internally by various government retirement funds such as the Social Security system. ${ }^{64}$ Those securities represent nothing more than accounting entries that credit the funds for previous overpayments, to be used to cover anticipated future payments if revenues fall short. They are, in other words, not current obligations. They only represent money that might need to be borrowed in the future, depending on future congressional choices about benefits and revenues in those programs.

Therefore, if the President were to unilaterally declare that the Social Security Trust Fund contained additional Treasury securities, he would violate the debt ceiling (assuming that the debt ceiling had already been reached). Because he would not have borrowed money on the credit of the United States from anyone outside of the government, however, he would not have usurped Congress's borrowing power, and he would thus not have committed a constitutional violation.

Certainly, however, defaulting on the government's external obligations would violate both the debt ceiling statute ${ }^{65}$ and the language of Article I, Section 8. ${ }^{66}$ The President, by forcing people to "agree" temporarily to allow the government not to pay them money to which they are entitled, would be borrowing money on the credit of the United States, in an amount that exceeds the total amount authorized by Congress. He would thus not only violate Congress's spending powers by defaulting on legal obligations, but he would do so by borrowing money from unwilling obligees.

Perhaps it could be argued that the "borrowing" power referenced in Article I only includes conventional, that is to say voluntary, loans. If so, an objection might go, when the President defaults he does not actually usurp congressional borrowing power, even if his action would increase the federal government's "obligations," as defined by the statute. But this objection fails for two reasons.

First, we have found nothing in the records of the Constitutional Convention, the ratification debates, or the postratification history that

63. See supra note 59 (citing Congress's use of word "debt" to describe money owed from one government account to another).

64. See 31 U.S.C. $\$ \$ 3101-3106$ (2012).

65. Id. $\$ 3101$ (b).

66. U.S. Const. art. I, $\$ 8$, cl. 2 ("The Congress shall have Power ... To borrow Money on the credit of the United States...."). 
suggests that forced loans are not loans. To be sure, Founding Era documents also do not affirmatively indicate that forced loans would be considered loans. The issue appears not to have arisen, in theory or in practice. From a purely semantic perspective, however, the original understanding appears to be consistent with the view expressed here. Thus, Samuel Johnson's 1755 Dictionary-the leading linguistic authority in the colonial era-provides, as its primary definition of "borrow," the following: "To take something from another upon credit." 67 Perhaps that definition implies consent of the borrower, but if so, Johnson's secondary definition-"To take something of another"68_makes clear that in the eighteenth century, as today, the term "borrow" could be used to encompass loans to which the lender does not consent.

Second, if congressional power to "borrow" only encompasses consensual loans, that merely exacerbates the constitutional offense. After all, if forced loans are not an exercise of the power to borrow money, then they are not an exercise of any enumerated power. Congress has the power to $\operatorname{tax}^{69}$ the Fifth Amendment's Takings Clause tacitly acknowledges congressional power to appropriate property if it provides just compensation; ${ }^{70}$ but no provision of the Constitution empowers Congress, the President, or any other federal actor to steal, so long as the stolen property is later returned. Thus, if the Article I power to borrow does not encompass forced loans, then presidential default would not merely amount to the exercise of power by the wrong branch; it would amount to the exercise of power that is denied to the federal government in its entirety.

Accordingly, whether or not Congress has the power to take forced loans, the President has no such power. Thus, a presidential decision to default rather than to issue new debt to voluntary purchasers would not substitute a Spending Clause ${ }^{71}$ violation for a Borrowing Clause ${ }^{72}$ violation. It would add a Spending Clause violation to a Borrowing Clause violation and/or a Tenth Amendment violation. ${ }^{73}$ By choosing default, the President would violate the Constitution twice (or perhaps even thrice) with one decision.

67. Samuel Johnson, A Dictionary of the English Language, at M4 (Dublin, W.G. Jones for Thomas Ewing, in Dames, $3 \mathrm{~d}$ ed. 1768), available at Google Books.

68. See id.

69. U.S. Const. art. I, $§ 8$.

70. See id. amend. V ("[N]or shall private property be taken for public use, without just compensation.”). But cf. William Baude, Rethinking the Federal Eminent Domain Power, 122 Yale L.J. 1738, 1792-93 (2013) (arguing that, as originally understood, Congress only had power of eminent domain with respect to property in federal territories).

71. U.S. Const. art. I, $§ 8$, cl. 1.

72. Id. cl. 2.

73. Id. amend. X. 


\section{THE UNEXPECTED INTERACTION BETWEEN THE FOURTEENTH AMENDMENT AND THE TRILEMMA ANALYSIS}

\section{A. The Public Debt Clause}

In our original article analyzing the President's options if Republicans were to refuse to increase the debt ceiling, we considered an argument based on the "public spending clause" of Section 4 of the Fourteenth Amendment. ${ }^{74}$ That clause specifies that the "validity of the public debt of the United States, authorized by law, including debts incurred for payment of pensions and bounties for services in suppressing insurrection or rebellion, shall not be questioned." 75 The argument is that the existence of a debt ceiling (and the potential of a default that the debt ceiling necessarily implies) brings the validity of the public debt into question, and thus violates the Constitution.

We concluded that there is much to be said for this argument. Even though "validity" and being "questioned" are hardly models of clarity in drafting, it is still reasonable to conclude that a law that raises the specter of default would violate that clause. ${ }^{76}$ We also addressed the question of what counts as "debt" under that Amendment, and we showed that the tendentious claim that it only includes Treasury securities (but excludes required payments under the appropriations laws) would logically-but absurdly - allow the government to default on interest payments, so long as it paid back the principal amounts borrowed. ${ }^{77}$

Even though we believe that there is merit to the argument that the debt ceiling statute violates the Fourteenth Amendment, we have become increasingly convinced that it is neither necessary nor prudent to rely on the Fourteenth Amendment to conclude that the debt ceiling is unconstitutional. If one were to agree with those who dismiss the Fourteenth Amendment argument, after all, one would still be left with the question of what the President must do if he is ever faced with a trilemma. The suggestion by politicians and commentators that the President can "choose to invoke the Fourteenth Amendment" implies that his constitutional obligations are somehow optional. ${ }^{78}$ Even if he were able to dismiss the Fourteenth Amendment argument, however, the President would not be in the clear. He would still have to make an unconstitutional choice.

74. See Buchanan \& Dorf, How to Choose, supra note 1, at 1205-08; see also U.S. Const. amend. XIV, $\S 4$.

75. U.S. Const. amend. XIV, §4.

76. Buchanan \& Dorf, How to Choose, supra note 1, at 1189-90.

77. See id. at $1180,1192$.

78. See, e.g., Adam Liptak, The 14th Amendment, the Debt Ceiling and a Way Out, N.Y. Times (July 24, 2011), http://www.nytimes.com/2011/07/25/us/politics/25legal. html (on file with the Columbia Law Review) (discussing President Obama's rejection of former President Clinton's suggestion that unilateral invocation of Fourteenth Amendment to raise debt ceiling would be constitutional). 
In any case, our trilemma-based argument has nothing to do with the Fourteenth Amendment. Similarly, our argument above that unilateral presidential decisions to default on obligations (in violation of Congress's spending power) simply are unilateral presidential borrowing is completely independent of any additional constitutional constraints imposed by Section 4 of the Fourteenth Amendment. We think that this logical independence is evident from what we have said here and elsewhere, but we make the point expressly because in public debate about the President's choices in the face of congressional failure to raise the debt ceiling, commentators frequently mistake any and all arguments about what the Constitution as a whole requires for arguments about what the Fourteenth Amendment in particular requires. ${ }^{79}$

\section{B. The Original Understanding of the Public Debt Clause}

Is there any basis for the conflation of our trilemma analysis with the Fourteenth Amendment argument? We can certainly imagine a critic objecting that our argument regarding the "least unconstitutional option" does depend on our view of the constraints imposed by Section 4 of the Fourteenth Amendment. Such critics have offered a very narrow reading of the Public Debt Clause, a reading under which only outright repudiation of federal debt is forbidden. ${ }^{80}$ Therefore, a critic could say that if the Reconstruction Congress thought it necessary to enact a prohibition on repudiation of debt, surely Article I could not have already forbidden mere temporary failure to pay promisees. For if such temporary failure to pay promisees were already forbidden, then, a fortiori, outright repudiation would also already have been forbidden, and there would have been no reason to add Section 4 of the Fourteenth Amendment to the Constitution.

What can we say in response to that (thus-far-only-hypothetical) objection? We could vigorously contest the claim that Section 4 only forbids outright repudiation, pointing to Perry $v$. United States ${ }^{81}$ and our prior exposition of the Clause, ${ }^{82}$ but doing so would only play into the critic's hands. "Aha!" we imagine him exclaiming. "So your latest argu-

79. See, e.g., Jeffrey Sparshott, Longshot Debt Ceiling Ideas Explained, Wall St. J.: Wash. Wire (Oct. 9, 2013, 5:26 PM), http://blogs.wsj.com/washwire/2013/10/09/ longshot-debt-ceiling-ideas-explained/ (on file with the Columbia Law Review) (discussing how attempt to rely on Fourteenth Amendment in isolation to grant President power to pay back public debt clashes with Congress's grant of power under Article I to "pay the debts").

80. See, e.g., McConnell, supra note 13 (reading "public debt" to include "public debts and pension obligations" but not any "other spending" required by law).

81. 294 U.S. 330, 354 (1935) (describing "validity of the public debt," as used in Section 4 of Fourteenth Amendment, "as embracing whatever concerns the integrity of the public obligations").

82. See Buchanan \& Dorf, How to Choose, supra note 1, at 1188-94 (arguing best reading of Section 4 would forbid more than outright repudiation). 
ment is dependent on your view of the Fourteenth Amendment, after all."

And indeed, that would be a fair rejoinder if all we could do is contest the critic's contention that Section 4 of the Fourteenth Amendment only forbids repudiation. But that is not all we have to say in response to the critic. Even conceding arguendo that the Fourteenth Amendment only forbids repudiation, the critic's attack misses its target.

In Part II, we explored the implications of the assumption that the power to borrow does not include the power to extract forced loans ${ }^{83} \mathrm{We}$ think that is a mistaken reading of the Constitution, but if it is correct, it creates more, not fewer, difficulties for a President who chooses to default. To return to our own affirmative argument, we emphasize that neither here nor in any of our prior work do we claim that Article I or the Tenth Amendment forbids the United States-as opposed to the President-from failing to pay promisees. Putting aside the Fourteenth Amendment, if the United States makes a contract to pay a firm for goods or services, and then receives those goods or services, but Congress refuses to allocate funds to pay the firm, the United States will have breached the contract and, absent renegotiation, will have extracted a forced loan from the contractor.

Even so, the United States will not have acted in violation of Article I, Section 8 or the Tenth Amendment. Put simply, our affirmative argument is that Article I forbids the President from borrowing money without congressional authorization, whether he does so by borrowing from voluntary participants in the bond markets or by borrowing from government obligees to whom he decides to delay payment. In either case, the President will have acted unconstitutionally because he will have usurped congressional power. But of course Congress cannot usurp congressional power, and so our trilemma argument in no way depends on any sort of claim that the antebellum Constitution forbade Congress from failing to pay its debts.

Thus we have a perfectly logical account of Section 4 of the Fourteenth Amendment, even assuming that it merely forbids repudiation. The Reconstruction Republicans feared that once the delegations from the states of the former Confederacy were readmitted to Congress, a majority of Congress might repudiate Union debt. ${ }^{84}$ As the price of readmission, these states were made to ratify the Fourteenth Amendment, including its Section $4 . .^{85}$

83. See supra Part II.B (discussing constitutional definition of "borrowing").

84. Jack Balkin, The Legislative History of Section Four of the Fourteenth Amendment, Balkinization (June 30, 2011), http://balkin.blogspot.com/2011/06/ legislative-history-of-section-four-of.html (on file with the Columbia Law Review).

85. 2 Bruce A. Ackerman, We the People: Transformations 230-34 (1998) (interpreting extraordinary ratification procedure as final stage in constitutional moment). 


\section{Repudiation and Default}

To this point, therefore, we have established that the trilemma-based analysis is independent of any claim that the debt ceiling runs afoul of Section 4 of the Fourteenth Amendment. It is important, however, to note an unexpected implication of the claim that the Public Debt Clause only forbids outright repudiation. Under this view, a President does not bring the validity of the public debt into question unless he announces that he will not repay that debt at all, not merely that he is delaying payment (with or without interest).

In Part II we noted that a President who wishes to avoid violating the debt ceiling could not merely say that he is not taking on additional debt by refusing to sell additional Treasury securities. ${ }^{86}$ Again, if he defaulted on obligations as they came due, he would be borrowing money from unwilling lenders, to be paid at a later date. This would amount to borrowing in excess of the debt ceiling, which in turn would violate the allocation to Congress of the borrowing power in Article I, Section 8.

The only way out of that difficulty would be for the President to repudiate those debts. He could not, moreover, simply refuse to call them debts, because until he repudiates them, they would be unpaid debts of the United States. To repudiate them is to acknowledge that they exist at all.

Therefore, even though we are willing to allow for the possibility that the critics of the Fourteenth Amendment argument might define the key terms of Section 4 in a way that would defeat the standalone Fourteenth Amendment argument, those definitions would ultimately come back to create a logical vise for the President. A presidential decision to default on the government's obligations would necessarily violate the Constitution in one of two ways (in addition to usurping Congress's spending power): Either that default would increase the debt, violating Article I, Section 8 , or that debt would have to be immediately repudiated, violating Section 4 of the Fourteenth Amendment.

\section{THe POLITICS OF TIMIDITY}

Here and in our prior work, we have treated the choices that a President would face if Congress fails to provide adequate borrowing authority as posing legal questions. Yet the debt ceiling crises present political questions as well. Some legal scholars have therefore suggested that our analysis is irrelevant. In one version of this critique, the President cannot follow any other course but default because to do so would be to fall into an impeachment trap. ${ }^{87}$ Yet the three parts of the trilemma combine to create an unavoidable impeachment trap, because

86. See supra notes $58-60$ and accompanying text.

87. Trevor Morrison, Professor, Columbia Law Sch., Statement at Columbia Law School Public Discussion (Feb. 21, 2013). 
any choice the President makes would violate the Constitution. ${ }^{88}$ In another, more radical version of this critique, a trilemma simply calls into play the President's supposed power to do what needs to be done to rescue the country, with legal mumbo-jumbo to be offered only as a fig leaf. ${ }^{89}$

Although we do not hold ourselves out as political experts, we do think that these criticisms are misguided to the extent that they treat politics as simply constraining the sorts of legal arguments that can be advanced. In fact, causation runs in both directions. Politics constrains legal options but legal arguments can also inform politics. More broadly, the boundaries of what is politically possible are not static.

The entire conversation around the debt ceiling reflects a too-timid view of the possibility that reason may inform politics. From the very beginning of the recent crises, we and all other responsible commentators have repeatedly urged Congress simply to repeal the debt ceiling statute, which serves no constructive purpose while threatening serious harm to financial markets and the real economy. ${ }^{90}$ Yet for political reasons, a Congress that prematurely turned to deficit reduction during a severe recession was deaf to that advice. To repeal the debt ceiling would be to invite the inane but inevitable charge of profligacy-even though the debt ceiling itself is utterly unnecessary to setting any particular level of government deficits and debts.

The White House has pushed back against the idea that a vote to increase the debt ceiling is a vote for profligacy, but the pushback only came after President Obama negotiated with House Republicans under threat of default in the summer of 2011. ${ }^{91}$ Moreover, the President and the Democratic Party generally accepted the dubious macroeconomic logic underlying the Republicans' premature push for deficit reduction, leaving them poorly positioned to make their case against anything

88. Neil H. Buchanan, Difficult Political Choices in the Shadow of the Debt Ceiling, Dorf on Law (Feb. 22, 2013, 11:00 AM), http://www.dorfonlaw.org/2013/02/difficultpoltical-choices-in-shadow-of.html (on file with the Columbia Law Review) (discussing trilemma and impeachment trap).

89. See Posner, supra note 39 (describing legal strategies as "legalistic argle-bargle necessary to take [the President] from A to B" if Congress refuses to raise debt limit).

90. See, e.g., Neil H. Buchanan \& Michael C. Dorf, Op-Ed., Obama Should Override the Debt Ceiling, CNN (Jan. 11, 2013, 11:18 AM), http://www.cnn.com/2013/01/11/ opinion/buchanan-dorf-debt-ceiling (on file with the Columbia Law Review) ("Our leaders can still act responsibly by raising the debt ceiling or, better yet, by repealing it entirely."); James Surowiecki, Smash the Ceiling, New Yorker (Aug. 1, 2011), http://www.newyorker. $\mathrm{com} / \mathrm{talk} /$ financial/2011/08/01/110801ta_talk_surowiecki (on file with the Columbia Law Review) (“[T]he United States doesn't need, and shouldn't have, a debt ceiling.").

91. See Brian Montopoli, Obama Signs Debt Limit Bill After Nasty Fight, CBS News (Aug. 2, 2011, 4:55 PM), http://www.cbsnews.com/news/obama-signs-debt-limit-bill-afternasty-fight/ (on file with the Columbia Law Review) (discussing President Obama's hardwon compromise to increase nation's borrowing power). 
called a "debt ceiling." 92 Perhaps pushback on the economics would not have been effective anyway. Since the early years of the Clinton Presidency, Democrats have sought to portray themselves, rather than Republicans, as the party of fiscal rectitude. ${ }^{93}$

Whatever factors explain the parties' positions on macroeconomic policy, the President has thus far missed an opportunity to shape-rather than merely react to- the legal conversation over debt ceiling doomsday scenarios. Threatening default as the inevitable outcome of a congressional failure to raise the debt ceiling is an effective strategy for ensuring that Congress raises the debt ceiling, in the same way that mutually assured destruction is an effective strategy for avoiding a nuclear waruntil it isn't. At that point, one must answer questions that one has been trying desperately to avoid.

We have previously explained why issuing new debt to cover the gap between authorized expenditures and revenues would be the least unconstitutional path in the post-apocalyptic world-and, we should add, the path most likely to minimize the extent of that apocalypse ${ }^{94}$ We have also explained why announcing that view in advance could make the apocalypse less likely. ${ }^{95}$ In this Essay, we have shown that the alternative that so much of the policy establishment embraces without explanation-presidential "spending cuts"-would not even honor the debt ceiling statute. It would have all of the flaws that we have previously noted, as well as the very flaws commonly attributed to unilateral presidential borrowing. The emperor has no clothes.

\section{CONCLUSION}

In our prior work, we argued that, when faced with a trilemma, issuing debt in violation of the debt ceiling would be the President's least unconstitutional option. We disagreed with those scholars and commen-

92. Cf. Ruy Teixeira, Does the Public Reward Obama's Proposals to Cut Entitlements?, ThinkProgress (Apr. 12, 2013, 10:50 AM), http://thinkprogress.org/ economy/2013/04/12/1857131/does-the-public-reward-obamas-proposals-to-cut-entitle ments/ (on file with the Columbia Law Review) (arguing President's compromise strategy unlikely to pay off or result in "elusive bipartisan Grand Bargain on debt reduction").

93. See Jonathan Martin, Some Democrats Look to Push Party Away From Center, N.Y. Times (July 24, 2013), http://www.nytimes.com/2013/07/25/us/politics/somedemocrats-look-to-push-party-away-from-center.html (on file with the Columbia Law Review) (describing "growing frustration among progressives" who want party to move towards more populist position of economic fairness).

94. Buchanan \& Dorf, Bargaining in the Shadow, supra note 1, at 53; Buchanan \& Dorf, Nullifying the Debt Ceiling, supra note 1, at 247-48.

95. See Buchanan \& Dorf, Nullifying the Debt Ceiling, supra note 1, at 248-49 (arguing Administration's refusal to acknowledge constitutional imperative to raise additional debt can hasten both default and constitutional crisis); Buchanan \& Dorf, Bargaining in the Shadow, supra note 1, at 51-52 (arguing same, even when Congress and President negotiate a budget with knowledge of impending exhaustion of borrowing authority under debt ceiling). 
tators who argued that, under such circumstances, the President should instead default on some government obligations, but we understood them to be arguing for an alternative to our proposal. Our analysis here shows that in fact default is not an alternative to borrowing in excess of the debt ceiling. It is simply a more dangerous, less effective, and more unconstitutional method of violating the debt ceiling.

Preferred Citation: Neil H. Buchanan \& Michael C. Dorf, Borrowing by Any Other Name: Why Presidential "Spending Cuts" Would Still Exceed the Debt Ceiling, 114 Colum. L. Rev. Sidebar 26 (2014), http://www. columbialawreview.org/Borrowing-by-any-other-name_Buchanan-and-Dorf. 